\title{
8
}

\section{PANDEMIA, CRISE DO CAPITAL E O APROFUNDAMENTO DA POBREZA DA CLASSE TRABALHADORA}

\author{
Pandemic, crisis of capitalism and the deepening working class poverty \\ Silvio Aparecido Redon* \\ https://orcid.org/0000-0002-6163-4846 \\ Eliane Christine Santos de Campos** \\ https://orcid.org/0000-0002-4435-2783
}

\begin{abstract}
RESUMO
Esse artigo se propõe a realizar uma exposição das consequências sociais e econômicas da nova crise do capital desencadeada pela crise sanitária, centrada na pandemia da COVID-19, que atingiu quase que a totalidade dos países do globo, não distinguindo-os entre centrais e periféricos, embora isso esteja longe de representar que esse vírus não encontre nas camadas pobres seu alvo predominante. Busca, através de revisão de literatura, uma compreensão da ideia de crise do capital a partir da teoria marxiana, além de indicar, via pesquisa documental em relatórios e demais publicações oficiais de organismos nacionais e internacionais, os principais desdobramentos para a população. A pesquisa demonstra que a atual situação, de crise econômica e de saúde, incide de forma violenta sobre a classe trabalhadora, com rebatimentos em seus níveis e condições de vida e sobrevivência, numa alarmante projeção do aumento e do agravo da pobreza mundial.
\end{abstract}

\section{PALAVRAS-CHAVE}

Pandemia. Crise do capitalismo. Pobreza.

\section{ABSTRACT}

This article proposes to present an explanation of the social and economic consequences of the new capital crisis triggered by the health crisis, centered on the COVID-19 pandemic, which as affected almost all the countries of the globe, not distinguishing them between central and peripheral, although this is far from

\footnotetext{
* Assistente Social. Mestre em Serviço Social e Política Social. Doutorando em Serviço Social e Política Social pela Programa de Pós-Graduação em Serviço Social e Política Social, pela Universidade Estadual de Londrina. (UEL, Londrina, Brasil). Rodovia Celso Garcia Cid, PR-445, Km 380, Campus Universitário (PR). CEP.: 86057970. E-mail: silvioredonks@hotmail.com.

${ }^{* *}$ Assistente Social. Doutorado em Serviço Social e Política Social. Professora titular da Universidade Estadual de Londrina - Departamento de Serviço Social. (UEL, Londrina, Brasil). Rodovia Celso Garcia Cid, PR-445, Km 380, Campus Universitário (PR). CEP.: 86057-970. E-mail: elianecampos@uel.br.
}

DOI 10.22422/temporalis.2021V21n41p256-269

๑ A(s) Autora(s)/O(s) Autor(es). 2019 Acesso Aberto Esta obra está licenciada sob os termos da Licença Creative Commons Atribuição 4.0 Internacional (https://creativecommons.org/licenses/by/4.o/deed.pt BR), que permite copiar e redistribuir o material em qualquer suporte ou formato, bem como adaptar, transformar e criar a partir deste material para qualquer fim, mesmo que comercial. O licenciante não pode revogar estes direitos desde que você respeite os termos da licença. 
representing this virus does not find its predominant target in the poor. It seeks, through literature review, an understanding of the idea of capital crises based on Marxian theory, in addition to indicating, through documentary research in reports and other official publications by national and international organizations, the main developments for the population. The research shows that the current situation, of economic and health crises, has a violent impact on the working class, with repercussions on their levels and conditions of life and survival, in an alarming projection of the increase and worsening of world poverty.

\section{KEYWORDS}

Pandemic. Crisis of capitalism. Poverty.

Submetido em: 21/1/2021.

Aceito em: 10/6/2021.

\section{INTRODUÇÃO}

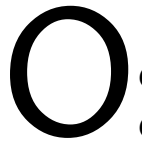

mundo está novamente às voltas com uma crise do sistema capitalista. Essas crises do capital são alvo de análises e debates de muitos estudiosos, resultando em divergentes interpretações teóricas. De forma suscinta, as ideias conflitantes gravitam em torno da discussão sobre sua intensidade, periodicidade e repercussão, objetivando enquadrar o evento da crise em um movimento cíclico ou estrutural; crises que devem ser apreendidas como constitutivas e inelimináveis do sistema capitalista. A crise põe e repõe, em escala ampliada, todas as contradições próprias do sistema. O capital se mostra extremamente predatório sobre as condições de vida da classe trabalhadora - fato agravado pela reestruturação produtiva, assentada nas últimas décadas pelo determinismo tecnológico, e pela irradiação mundial da argumentação neoliberal, ambas como formas de enfrentamento dos limites da expansão econômica que já se anunciava no final da década de 1960 (MANDEL, 1982).

Esse artigo tem por objetivo uma reflexão sobre as crises do sistema capitalista, especificamente problematizando o momento atual, de uma crise de saúde planetária, deflagrada por um novo e mortal vírus, que denuncia a fragilidade dos sistemas de proteção social em grande parte dos países, inclusive os localizados nas regiões centrais do capitalismo, e sumaria as principais consequências para classe trabalhadora, com graves repercussões em suas condições de vida. O texto, está organizado em dois tópicos: em Caracterização de elementos estruturais para a compreensão da crise do capital, serão apresentados alguns elementos para uma aproximação à ideia de crise do sistema capitalista, já aprofundados e expostos na análise marxiana da sociedade burguesa. No segundo item, A crise atual, o vírus e a classe trabalhadora, a intenção é situar o presente momento de crise, evidenciando seus principais delineamentos e suas imediatas consequências para a classe trabalhadora mundial. Tópicos seguidos de uma breve conclusão.

\section{CARACTERIZAÇÃO DE ELEMENTOS ESTRUTURAIS PARA A COMPREENSÃO DA CRISE DO CAPITAL}

Já em 1848, no Manifesto Comunista, Marx e Engels (2010) apontavam a "[...] epidemia de superprodução [...]": "[...] a sociedade vê-se subitamente reconduzida a um estado de barbárie momentânea; como se a fome ou uma guerra de extermínio houvessem lhe cortado todos os meios de sobrevivência; o comércio e a indústria parecem aniquilados" (MARX; ENGELS, 2010, p. 45). Os autores indicam uma certa "periodicidade" das crises, nos

Temporalis, Brasília (DF), ano 21, n. 41, p. 256-269, jan./jun. 2021. | ISSN 2238-1856 
alertando para uma compreensão que a concebe como episódios cíclicos. As soluções previstas seriam a destruição das forças produtivas e também a abertura de novos mercados, ou a intensificação da exploração dos já existentes. Isso resultaria em novas crises, "mais extensas e destruidoras e a diminuição dos meios de evitá-las" (MARX; ENGELS, 2010, p. 45), o que sugere o desenvolvimento para um quadro estrutural de crise, em que esta se tornaria sistêmica, afunilando as possibilidades de sua superação. Segundo Harvey (2018), no esforço monumental de Marx em compreender o funcionamento do capital, seu interesse particular estava em "[...] descobrir por que o capitalismo parecia ser tão propenso a crises” (HARVEY, 2018, p. 11).

As crises econômicas, sob o vigente sistema de produção, divergem das anteriores. Segundo Netto e Braz (2012), as crises nas sociedades pré-capitalistas, que certamente produziam miséria e pobreza, decorriam da destruição dos produtores e dos meios de produção, originadas de catástrofes naturais ou sociais, como guerras ou epidemias ${ }^{1}$; essas crises são compreendidas como de "subprodução de valores de uso" (NETTO; BRAZ, 2012, p. 170, grifo dos autores). Contrariamente no que Marx (1984, p. 196) denominou "[...] modo de produção especificamente capitalista [...]"2, a crise decorre da "superprodução de valores de uso"; de forma simplificada, o desemprego é gerado pela diminuição da produção devido à queda da taxa de lucro e, com isso, as mercadorias não encontram vazão na esfera da circulação devido à falta de consumidores. A produção é travada, já que a oferta excede a demanda, e restringida ao seu limite. Para melhor entendermos isso, sigamos as indicações de Marx (1984).

\begin{abstract}
A transformação de uma soma de dinheiro em meios de produção e força de trabalho é o primeiro movimento pelo qual passa um quantum de valor que deve funcionar como capital. Ela tem lugar no mercado, na esfera da circulação. A segunda fase do movimento, o processo de produção, está encerrada tão logo os meios de produção estejam transformados em mercadorias cujo valor supera o valor de seus componentes, portanto, que contenha o capital originalmente adiantado mais uma mais-valia. Essas mercadorias a seguir têm de ser lançadas de novo à esfera da circulação. Trata-se de vendê-las, realizar seu valor em dinheiro, transformar novamente esse dinheiro em capital, e assim sempre de novo. Esse ciclo, que percorre sempre as mesmas fases sucessivas, constitui a circulação do capital (MARX, 1984, p. 151, grifo nosso).
\end{abstract}

É no momento de interrupção, ou perturbação, da circulação do capital que a crise se instaura. O capital, enquanto valor em movimento, necessita dessa dinamicidade para se

\footnotetext{
${ }^{1}$ Um exemplo clássico é a Peste Negra, que assolou a Europa entre os anos de 1348 e 1350, ressurgindo em alguns países décadas depois, matando mais gente, no século XIV, do que a Primeira Guerra Mundial. A cidade de Florença perdeu 100 mil vidas; em Londres morria cerca de 200 pessoas por dia, e 800 em Paris. Na França, Inglaterra, Países Baixos e Alemanha, entre um terço e metade da população foi dizimada (HUBERMAN, 1982).

${ }^{2}$ Conceito que, em Marx, designa o resultado total das relações antagônicas: capital e trabalho, proletariado e burguesia. Mas estas relações antagônicas não entram na prática social da sociedade burguesa de forma clara, sendo necessário sua mistificação, como a forma contratual de trabalho que expressa a "liberdade" do trabalhador. Assim, esse resultado global compreende "[...] as elaborações jurídicas das relações de produção, as relações de propriedade codificadas - as ideologias que 'exprimem' também, dissimulando-as, as relações de antagonismo - as instituições políticas e 'culturais', a ciência, etc." (LEFEBVRE, 1977, p. 220). Devido ao caráter imediato com que a prática social se evidencia no cotidiano, encobrindo suas reais mediações e contradições, se coloca a importância do método de Marx para a apreensão da realidade como uma totalidade complexa e em movimento.
} 
valorizar - é dessa forma que ele deve ser compreendido e problematizado. É no processo de produção ${ }^{3}$, já com as forças produtivas adquiridas, que acontece o que Marx chama de valorização do capital ${ }^{4}$; contudo, para que a acumulação de capital se efetive, é necessário que o capitalista consiga vender suas mercadorias na esfera da circulação e reconverter a maior parte do dinheiro em capital5: "[...] é pressuposto, a seguir, que o capital percorra seu processo de circulação de modo normal" (MARX, 1984, p. 151). Essa fala de Marx nos atesta dois elementos: um, que o sistema está propenso a crises, como algo interno e inerente ao sistema capitalista e, outro, que a circulação do capital, caso interrompida, incide sobre seu movimento, tendo por desdobramento a estagnação, mesmo que de forma momentânea, da possibilidade de acumulação.

No capítulo XXIII do Livro I de O Capital, A Lei Geral da Acumulação Capitalista, Marx (1984), se dedica ao estudo da "[...] influência que o crescimento do capital exerce sobre o destino da classe trabalhadora. Os fatores mais importantes nessa investigação são a composição do capital e as modificações que ela sofre no transcurso do processo de acumulação" (MARX, 1984, p. 187). Essa lei não é uma teorização sobre a pobreza, mas sobre a necessidade de o capital potencializar as forças produtivas de forma contínua para garantir a acumulação, acarretando consequências desastrosas para a classe trabalhadora. $A$ questão da tecnologia é de grande importância para a análise de Marx, evidenciando uma contradição dessa alteração da composição orgânica do capital: quanto mais dinâmica e inovadora a tecnologia incorporada ao processo produtivo, menor a necessidade de força de trabalho humana para movimentar uma massa crescente de meios de produção devido ao aumento da produtividade do trabalho ${ }^{6}$. Assim, menos trabalho é cristalizado nas mercadorias, que necessitam serem vendidas em maior quantidade e menos tempo para manter a acumulação: há uma relação direta entre o aumento da produtividade e a imprescindível dinamização do mercado7. Em uma economia de concorrência, o capital não pode escapar desse imperativo:

Em uma economia organizada competitivamente, a luta entre as firmas em busca de vantagens tecnológicas produz um padrão de saltos inovadores nas formas

\footnotetext{
3 Devemos considerar que o processo de produção é também o de reprodução. Dessa forma, qualquer que seja a forma de produção da vida social, ela não deve cessar, sendo contínua e percorrendo as mesmas fases, visto que uma sociedade não pode deixar de consumir e de produzir. Considerando sua conexão e fluxo, "[...] todo processo de social de produção é, portanto, ao mesmo tempo, processo de reprodução". "Se a produção tem a forma capitalista, então a terá a reprodução" (MARX, 1984, p. 153).

${ }^{4}$ Especificamente na nossa discussão, restrita aos limites do capitalismo: "Como no momento de produção capitalista o processo de trabalho só aparece como meio para o processo de valorização, assim a reprodução aparece apenas como meio para reproduzir o valor adiantado como capital, isto é, como valor que se valoriza" (MARX, 1984, p. 153, grifo nosso).

5 Importante ressaltar que a transformação de dinheiro em capital não se limita a produção de mercadorias e sua circulação, mas é condição primordial o confronto, na esfera do mercado entre, de um lado, os possuidores do dinheiro e dos meios de produção e, de outro, os possuidores apenas da força de trabalho, como substância criadora de valor (Consultar Marx, Seção II, A transformação do dinheiro em capital; Cap. IV, Transformação do dinheiro em capital. O Capital, Volume I).

${ }^{6}$ De acordo com Marx (1984), o grau de desenvolvimento da produtividade do trabalho se "expressa no volume relativo dos meios de produção que um trabalhador, durante um tempo dado, com o mesmo dispêndio de força de trabalho, transforma em produto. A massa dos meios de produção com que ele funciona cresce com a produtividade do seu trabalho" (MARX, 1984, p. 194).

${ }^{7}$ Aqui se coloca a importância das características da mercadoria elencadas por Netto (2012): obsolescência programada, fungibilidade e sua imediaticidade reificante. Além da moda.
}

Temporalis, Brasília (DF), ano 21, n. 41, p. 256-269, jan./jun. 2021. | ISSN 2238-1856 
tecnológicas e organizacionais. Por esse motivo, o capital se torna uma força permanentemente revolucionária na história do mundo. A base tecnológica da atividade produtiva está em constante transformação (HARVEY, 2018, p. 22-23).

Essa busca por lucros, em um panorama de livre concorrência, oportunizada pela alteração da composição do capital, atesta a capacidade crescente do capital potencializar a exploração do trabalho pelo aumento de sua produtividade. Além disso, é responsável pela produção do exército industrial de reserva ${ }^{8}$ em seus diversos matizes, que incide sobre o movimento dos salários; segundo Marx (1984, p. 209), "a força de trabalho disponível é desenvolvida pelas mesmas causas que a força expansiva do capital”, ou grosseiramente falando, pelo progresso. E esse contingente de trabalhadores apartados do processo produtivo cresce na mesma razão da capacidade expansiva do capital produzir riquezas. Quanto maior essa parcela de proletariados inativos em contraponto aos ativos, maior sua miséria e o exército industrial de reserva, tanto maior, portanto, o pauperismo oficial. Se impõe a "lei absoluta geral, da acumulação capitalista" (MARX, 1984, p. 209, grifo do autor), como expressão direta da alteração da composição orgânica do capital.

É no Livro II de O Capital, dedicado à realização do mais-valor, que Marx aponta uma ideia, ainda a ser desenvolvida, mas que demonstra a incoerência do movimento contraditório do capitalismo nessa busca pela garantia de lucros:

\begin{abstract}
Contradição no modo de produção capitalista: os trabalhadores como compradores de mercadoria são importantes para o mercado. Mas, como vendedores de suas mercadorias - da força de trabalho -, a sociedade capitalista tem a tendência de reduzi-lo ao mínimo do preço. Contradição adicional: as épocas em que a produção capitalista usa todas as suas potências se revelam regularmente como épocas de superprodução, porque os potenciais de produção nunca podem ser aplicados ao ponto de que, assim, mais valor possa ser não só produzido, mas também realizado; a venda das mercadorias, a realização do capital-mercadoria, portanto também da mais-valia, é, no entanto limitada não pelas necessidades de consumo da sociedade, [mas pelas necessidades de consumo de uma sociedade] em que a grande maioria é sempre pobre e tem de continuar pobre (MARX, 1983a, p. 234).
\end{abstract}

Há, portanto, uma disjunção entre o objetivo do capital, o lucro, e a forma pela qual se dá essa busca: a constante incorporação da tecnologia age como uma força disruptiva no sistema capitalista, implodindo a circulação do capital e contrarrestando as possibilidades de sua valorização. É, segundo Sweezy (1982) dessa tendência apontada por Marx, o aumento da produtividade do trabalho social em decorrência da alteração da composição do capital ${ }^{9}$, que sobressai sua famosa dedução expressa na Lei da Tendência Decrescente da Taxa de

\footnotetext{
${ }^{8}$ Exército Industrial de Reserva que é, grosso modo, responsável pelas oscilações gerais dos salários quando aquele se expande e se contrai, acompanhando a mudança periódica do ciclo industrial (MARX, 1984).

9 “A acumulação de capital é acompanhada pela mecanização progressiva do processo de produção. A mesma quantidade de trabalho, operando com equipamento mais complexo e mais eficiente, pode processar maior volume de material e produzir um número crescente de artigos. Desse ponto de vista, isso significa que a produtividade do trabalho cresce continuamente; de outro ponto, significa que a composição orgânica do capital (a razão entre investimento em material e máquina e o investimento total) também demonstra uma tendência para crescer firmemente. Dessas tendências indiscutíveis, Marx deduziu sua famosa "lei da tendência decrescente da taxa de lucro"” (SWEEZY, 1982, p. 124).
} 


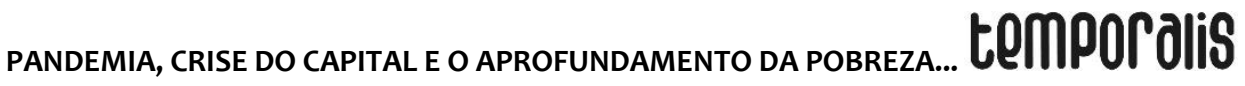

Lucro $^{10}$. Lei, que segundo Colletti (1978) se estabelece como um limite para a acumulação ampliada ${ }^{11}$.

Marx (1983b) aponta que esse crescimento do capital constante frente ao variável, como uma lei do processo produtivo sob condições capitalistas, tem "[...] necessariamente por resultado uma queda gradual na taxa de lucro geral" (MARX, 1983b, p. 163, grifo do autor). Desse fato resulta que um número relativamente menor de trabalhadores opere sempre uma quantidade maior de capital constante, produzindo com menos tempo de trabalho:

Corresponde a esse crescente volume de valor do capital constante [...] um crescente barateamento do produto. Cada produto individual, considerado em si, contém uma soma menor de trabalho do que em estágios inferiores da produção, onde $\mathrm{o}$ capital desembolsado em trabalho está numa proporção incomparavelmente maior em relação ao desembolsado em meios de produção. [...] A tendência progressiva da taxa geral de lucro a cair é, portanto, apenas uma expressão peculiar ao modo de produção capitalista para o desenvolvimento progressivo da força produtiva social do trabalho (MARX, 1983b, p. 164, grifo do autor).

Da análise de Marx, resulta que o capitalismo incorre em um movimento para a ampliação da acumulação que acaba por evidenciar seu caráter contraditório, expressando os limites da busca por obtenção de lucros que ocasionam crises e desemprego. Ora, o desenvolvimento do processo produtivo acarreta uma diminuição do capital variável e um aumento do capital constante: cada vez menos precisa-se empregar trabalhadores para mover a produção, o que resulta em uma menor extração de mais-valia, o que gera um aumento da população de trabalhadores sobrantes, desempregados, que não se colocam como consumidores. Esse descompasso se "[...] origina da exploração capitalista do trabalho, pela desproporção entre o crescimento cada vez maior do capital e sua necessidade relativamente decrescente de uma população crescente" (MARX, 1983b, p. 170). A importância da tendência da queda da taxa de lucro ${ }^{12}$ para a formação de crises está em que:

[...] ela promove superprodução, especulação, crises, capital supérfluo, ao lado de população supérflua. [...] o modo de produção capitalista encontra no

\footnotetext{
${ }^{10}$ As análises dessa lei encontram-se no Livro III, de O Capital, na Seção III - Lei da Queda Tendencial da Taxa de Lucro.

${ }^{11}$ Importante ressaltar que essa a Lei da Tendência Decrescente da Taxa de Lucro possui um caráter tendencial. Marx discorre no Livro III sobre as "[...] causas contrariantes [...]", que "[...] cruzam e superam os efeitos da lei geral" (MARX, 1983b, p. 177).

${ }^{12}$ Além da tendência a queda da taxa de lucro, Netto e Braz (2012) apontam como pontos contraditórios do sistema e que, portanto, se configuram como elementos para a irrupção das crises: a anarquia da produção em que, por mais que essa seja cada vez mais organizada e racionalizada, não há um planejamento por parte dos capitalistas e o mercado é inundado por mercadorias sem destino certo; e o subconsumo das massas de trabalhadores, a permanente limitação dos trabalhadores em consumir perante a não ampliação da capacidade aquisitiva. Mas a fundamental contradição do capitalismo, das quais derivam todas as outras é a contradição entre a produção socializada e apropriação privada. A prioridade desse enfoque, a tendência à queda da taxa de lucro, além dos limites do artigo, está justificada em Harvey (2013): a exposição da lei dos lucros decrescentes para Marx se consistiria na "[...] declaração do 'primeiro recorte' de sua teoria da formação de crise no capitalismo" (HARVEY, 2013, p. 304). Na verdade, é mais que isso: "Ela revela [...] as justificativas básicas para a evidente instabilidade do capitalismo como um modo de organização econômica e social” (HARVEY, 2013, p. 305).
}

Temporalis, Brasília (DF), ano 21, n. 41, p. 256-269, jan./jun. 2021. | ISSN 2238-1856 
desenvolvimento das forças produtivas uma barreira que nada tem a ver com a produção da riqueza enquanto tal; e essa barreira popular testemunha a limitação e o caráter tão somente histórico e transitório do modo de produção capitalista; testemunha que ele não é um modo de produção absoluto para a produção de riqueza, mas que antes entra em conflito com seu desenvolvimento, em certo estágio (MARX, 1983b, p. 183-184).

Esses são alguns dos aspectos gerais e contrariantes da produção capitalista. Ressalta-se que todo esse movimento, em escala global, faz parte da natureza do sistema capitalista. A crise é, portanto, intrínseca ao sistema e se apresenta como algo inevitável, dado seu objetivo e configurações. Importante compreender que, frente às crises, o capital reage, e de maneiras diferentes: se num determinado momento histórico temos a edificação de sistemas de proteção social robustos, caracterizados pela forte presença do Estado na garantia de emprego e na geração da demanda efetiva, envolvendo um pacto entre classes, dinamizando a economia e marcando uma quadra de forte e intensa acumulação capitalista, em um outro período temos um ataque desferido sobre essa complexa organização, representando a subtração de direitos e a condenação da presença estatal em meio à uma reestruturação das formas de produção e de condução política, cujas problematizações encontram-se sintetizadas na argumentação teórica do neoliberalismo.

\section{A CRISE ATUAL: O víRUS E A CLASSE TRABALHADORA}

Em março de 2019, cientistas chineses publicaram um estudo, Bat Coronaviruses in China, alertando para a possibilidade do desencadeamento de um novo surto de corona vírus, provenientes de morcegos, animais agora conhecidos como importantes hospedeiros reservatórios de CoVs: “[...] é altamente provável que surtos futuros de SARS ou de corona vírus semelhantes ao MERS se originem de morcegos, e há uma probabilidade maior de que isso ocorra na China13" (FAN; ZHAO; SHI; ZHOU, 2019, não paginado). Em menos de um ano esse cenário deixou de ser uma previsão apocalíptica para se colocar como uma realidade que alterou substancialmente o mundo em que vivemos. Deflagou uma grave crise econômica, denunciou o despreparo e o descaso global do capitalismo no enfrentamento de situações perigosas e urgentes para a manutenção da vida graças, em grande parte, às medidas neoliberais adotadas pelos países ao longo dos últimos quarenta anos, além de incidir prioritariamente sobre a classe trabalhadora, e de forma mais violenta em suas camadas mais pobres e condenadas pela sociedade ao descaso - população mais exposta, com mínimas ou nenhuma condições de prevenção, que compõe a maioria dos milhares de mortes registradas.

Tendo em conta a dinâmica do modelo econômico como já exposto, era questão de momento até que um detonador iria impor uma ruptura na continuidade do ciclo do capital, gerando a

\footnotetext{
${ }^{13}$ E por que a China? Segundo os cientistas, a explicação está em que: "A China é o terceiro maior território e também a nação mais populosa do mundo. Uma vasta pátria mais diversos climas trazem grande biodiversidade, incluindo a de morcegos e vírus transmitidos por morcegos [...]. A maioria dos CoVs pode ser encontrada na China. Além disso, a maioria dos morcegos hospedeiros desses CoVs vive perto de humanos, potencialmente transmitindo vírus a humanos e animais domésticos. A cultura alimentar chinesa afirma que animais vivos abatidos são mais nutritivos e essa crença pode aumentar a transmissão viral. Em geral, acredita-se que os CoVs transmitidos por morcegos ressurgirão para causar o próximo surto de doença. Nesse sentido, a China é um provável hotspot. O desafio é prever quando e onde, para que possamos dar o nosso melhor para prevenir esses surtos" (FAN; ZHAO; SHI; ZHOU, 2019, não paginado).
} 
desvalorização que sinalizaria o início da crise. Importante frisar, como quer Harvey (2020), que o modelo neoliberal de acumulação já estava com sérios problemas: “[...] Já enfrenta o problema da insuficiente demanda para realizar os valores que o capital é capaz de produzir" (HARVEY, 2020, p. 14). Queremos enfatizar que a atual crise do capital não pode ser explicada apenas pela crise de saúde; estruturalmente, o capitalismo vive em crise desde os anos 1970: "[...] crise estrutural afeta a totalidade de um complexo social em todas as relações com suas partes constituinte ou subcomplexos, como também a outros complexos aos quais é articulada" (MÉSZÁROS, 2011, p. 796). Agora, estamos diante de mais um agravamento desse quadro, numa clássica crise de superprodução, como nos esclarece a professora Virgínia Fontes:

\begin{abstract}
Antes de falar da crise sanitária, é preciso lembrar que já estávamos ingressando numa nova crise capitalista, de novo por superprodução de capitais, pois o enorme volume de capitais, sob forma de títulos ou de dinheiro, que precisam se valorizar, já estavam implodindo a vida social. Longe da falaciosa versão de que 'vínhamos crescendo e o vírus pode atrapalhar', apresentada por Trump e por Bolsonaro, a crise já estava em curso, e era anunciada pelos próprios economistas burgueses (FONTES, 2020, não paginado).
\end{abstract}

Portanto, o vírus não foi a causa, mas o detonador de um panorama profundo de crise do sistema capitalista; é o capitalismo, em sua reprodução e expansão, que cria as condições para quadros pandêmicos devido à sua relação destrutiva com a natureza ${ }^{14}$ (PINTO; CERQUEIRA, 2020; FONTES, 2020; HARVEY, 2020). De acordo com Pinto e Cerqueira (2020), "[...] os dados econômicos, analisados e divulgados por estudiosos do mundo, e mesmo do campo dos dominantes, dão a conhecer que a economia mundial já vinha em processo de desaceleração desigual mundo à fora, com contração da produção nacional e de investimentos" (PINTO; CERQUEIRA, 2020, p. 42). De início, o surto de COVID-19 foi minimizado, muito por causa da forma como a China lidou com o caso, buscando sua contenção" "começaram a circular histórias [que foram ignoradas ou mal interpretadas] de suspensão nas cadeias de produção globais que passavam por Wuhan. [...] Os sinais de queda da demanda dos consumidores também foram minimizados" (HARVEY, 2020, p. 17). Mas o impacto do vírus não podia mais ser ignorado com o surto italiano, desvalorizando as bolsas de valores do mundo em quase $30 \%$.

Os efeitos econômicos agora estão fora de controle, tanto dentro da China como fora dela. [...] A ruptura das cadeias produtivas implica demissões ou corte de trabalhadores, o que diminui a procura final, enquanto a procura de matériasprimas diminui o consumo produtivo (HARVEY, 2020, p. 19).

\footnotetext{
14“Há estudos que demonstram que as novas epidemias (SARS, Ebola, os vários tipos de influenzas, entre outros patógenos) ocorrem devido ao modelo de agricultura e criação de animais altamente extensivo. Este modelo que diminui a distância entre o mundo rural e o urbano e fundamentalmente as barreiras naturais entre a civilização e os animais e seus respectivos, e, singulares, 'habitats', expõe a humanidade diretamente a vírus e bactérias que, até então, não se encontrava exposta" (PINTO; CERQUEIRA, 2020, p. 44).

15 Contudo, medidas não aplicáveis a outros países, especialmente se considerarmos as práticas democráticas, cuja realidade não se aplica à China. O país em questão possui um amplo e funcional sistema de controle de vigilância da população, estabelecendo normais sociais rígidas. No caso da pandemia, foi capaz de instituir um isolamento social forçado, numa província onde vivem 60 milhões de pessoas, criando a "[...] impressão de um enorme campo de concentração a céu aberto pela imposição da quarentena a todos os seus habitantes" (ZIBECHI, 2020, p. 31).
}

Temporalis, Brasília (DF), ano 21, n. 41, p. 256-269, jan./jun. 2021. | ISSN 2238-1856 
E, como em toda crise, temos as evitais, e injustificáveis, consequências para a classe trabalhadora, agravadas pela opção política de Estados e empresários socorrerem empresas e bancos, em detrimento da população. Primeiramente, as condições precárias, ou insuficientes, de uma estrutura mundial de saúde que é, de fato, encarada como uma rica fonte de investimentos de capitais e não como uma política pública essencial, que deveria ser universalmente acessível pela população. Meios de comunicação de todo mundo relatam a precariedade e o colapso dos sistemas de saúde e funeral frente à letalidade e rápida disseminação do vírus. Esse é um momento de pandemia que expõe, de forma crua, a característica divisão de classes de nossa sociedade, mesmo em países ricos, como os Estados Unidos, o coração do capitalismo. Um mundo em que a grande maioria das pessoas são impedidas de cumprirem as medidas de prevenção definidas pela Organização Mundial da Saúde (OMS) ao corona vírus, desde a utilização de máscara e álcool gel, até as recomendações de isolamento e distanciamento social. Olhemos para o nosso mundo de forma mais detalhada, para sabermos do que estamos falando.

1- Quase metade da população mundial, 3.4 bilhões de pessoas, lutam para satisfazer suas necessidades básicas (BANCO MUNDIAL, 2018);

2- 821 milhões de pessoas passam fome no mundo (39.3 milhões na América Latina) (FAO, 2018);

3- 2.2 bilhões de pessoas não tem serviços de água potável gerenciados de forma segura;

4- 4.2 bilhões de pessoas não tem acesso a esgoto sanitário seguro;

5- 3 bilhões de pessoas não tem instalações básicas para lavar as mãos de forma adequada;

6- 785 milhões de pessoas não tem acesso a nenhum tipo de serviço básico de água potável;

7- 144 milhões de pessoas consomem água sem tratamento;

8- 673 milhões de pessoas fazem suas necessidades fisiológicas à céu aberto;

9- Todos dos anos, 297 mil crianças com menos de 5 anos morrem por diarreia associada à água, saneamento básicos e higiene inadequados (NAÇÕES UNIDAS, 2019).

Os dados informam que a maior parte da população está exposta à pandemia da COVID-19. Pessoas que não acessam o básico para a vida e higiene, estando impedidas de realizarem a prevenção contra a doença. Pessoas que vivem, em sua maioria, na África Subsaariana, Sul da Ásia e América Latina, revelando a geografia da pobreza. O Fundo Monetário Internacional (FMI) destacou essa como sendo uma crise que não se via desde a Grande Recessão de 1929. Estima-se uma queda de 4,9\% na economia global (para o Brasil, a projeção é uma queda espetacular de 9,1\%), indicando uma recessão mais profunda e com retomada mais lenta do que se pensava. Esses são dados apresentados no Relatório, do FMI, World Economic Outlook, divulgado em junho, que ainda alerta que os resultados de duas décadas de luta contra a pobreza extrema podem estar em perigo. Segundo a economista da organização, Gina Gopinath, essa é uma crise econômica diferente de tudo o que o mundo já viu, trazendo consequências devastadoras para os pobres (CRISE..., 2020). São os pobres, juntamente com os negros, as maiores vítimas da pandemia no Brasil e no mundo (GRAGNANI, 2020): pessoas que trabalham na linha de frente no tratamento 


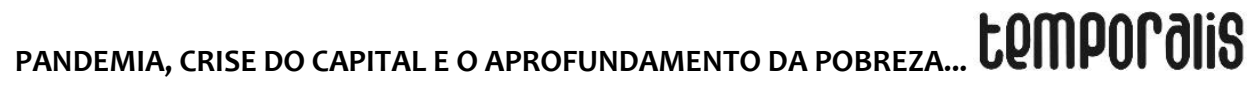

à COVID-19, trabalhadores em serviços essenciais ou em empregos informais que não puderam se afastar das atividades.

Um estudo, envolvendo pesquisadores da Inglaterra e Austrália e as Nações Unidas, divulgado por Barrucho (2020) da BBC Brasil em Londres, analisou três possíveis cenários para a recessão, com queda de consumo e renda de 5\%, 10\% e 20\%. Na pior das hipóteses, e considerando a linha da pobreza de U\$ 5,50 ao dia, a previsão é de 527,2 milhões de novos pobres no mundo. Ainda nessa linha de argumentação, a população que vive na extrema pobreza saltaria dos atuais 727,3 milhões de pessoas para assustadores 1,1 bilhão - para além desse dado quantitativo, a pesquisa revela que a severidade da pobreza para essas pessoas poderia aumentar em $60 \%$. Particularmente no Brasil, e considerando os mesmos índices, de pobreza e extrema pobreza, aos atuais números podem ser acrescidos mais 14 milhões e 1,5 milhão de pessoas, respectivamente.

O Relatório Informe de los Objetivos de Desarrollo Sostenible (NACIONES UNIDAS, 2020) admite que a população marginalizada das economias desenvolvidas e os países em desenvolvimento sofrem de forma particular as consequências da crise. A previsão é que a crise empurre 71 milhões de pessoas para a extrema pobreza (pessoas que vivem com até U\$ 1,90 ao dia, segundo a linha estabelecida pelo Banco Mundial), o que seria o primeiro aumento da pobreza mundial desde 1998. Além das interrupções de práticas sanitaristas, como a calendário de vacinas, e o aumento de denúncias de violência doméstica, cerca de 370 milhões de crianças deixaram de ter acesso à merenda escolar. E à medida que aumenta o número de famílias que caem na extrema pobreza, aumentam as chances de as crianças estarem expostas ao trabalho e matrimônio infantil. Contudo, em recente relatório, o Banco Mundial (2020) retoma estudos anteriores e faz uma projeção mais alarmante. Apontando que a pobreza deverá aumentar pela primeira vez em 20 anos, estima que o número de pessoas condenadas à pobreza extrema pela pandemia de COVID-19 poderá variar entre 88 milhões e 115 milhões de pessoas somente este ano, número que pode alcançar a marca de 150 milhões em 2021.

Formada por um grupo de organizações não governamentais independentes e presente em mais de 90 países, a Oxfam sumariou, em poucas páginas, um panorama desalentador sobre uma questão extremamente controversa de nossa sociedade: a fome mundial. Controversa por que, segundo a mesma publicação, o sistema alimentar "[...] tem mantido milhões de pessoas em situação de fome em um planeta que produz alimentos mais que suficientes para todos" (OXFAM, 2020, p. 2). A Oxfam expõe que a crise da fome já vinha se intensificando antes da pandemia: cerca de 821 milhões de pessoas viviam em insegurança alimentar, das quais 149 milhões já estavam em situação de crise de fome. A crise sanitária agravou um mundo já extremamente conturbado pela desigualdade, conflitos e crise climática. Segundo o Programa Mundial de Alimentos (PMA), o número de pessoas que em situação de crise de fome subirá para lamentáveis 270 milhões de pessoas antes do final do ano. Até essa data, de 6 mil a 12 mil pessoas poderão morrer de fome por dia devido aos impactos sociais e econômicos da pandemia.

A perspectiva era que só a crise climática, até 2050, condenaria mais 183 milhões de pessoas aos índices da fome. O conflito é apontado como causa e consequência da escassez de alimentos ( 8 em cada 10 países afetados pela fome estão em conflito). A pandemia 
exacerba a desigualdade social, “[...] na medida em que os que estão na base da pirâmide social são os mais impactados pela perda de empregos e renda" (OXFAM, 2020, p. 12). Segundo a Organização Internacional de Trabalho (OIT), 305 milhões de empregos em tempo integral foram perdidos pela pandemia, em um mundo que $61 \%$ das pessoas trabalham na economia informal. Isso agrava a situação de famílias pobres que contavam com o fluxo de remessas (dinheiro que trabalhadores migrantes enviam para suas famílias). A queda, em decorrência do desemprego, foi de 20\%, somando 100 bilhões de dólares; as remessas globais, em 2019, totalizaram 554 bilhões de dólares.

Além do aumento da fome nos países em que esta já era a realidade ${ }^{16}$, há o surgimento de outras nações que estão ingressando nesse panorama, como Brasil ${ }^{17}$, Índia e África do Sul. Até mesmo países ricos revelam essa tendência, como o Reino Unido. No Brasil, um estudo de Marcelo Neri (2020), divulgado pela FGV Social, indica que no primeiro trimestre da pandemia a renda do trabalhador brasileiro caiu, em média, 20,1\%. Mas esse impacto foi significativamente mais acentuado na renda da metade mais pobre da população, atingindo $27,9 \%$, contra $17,5 \%$ para os mais ricos brasileiros.

As consequências dessa conjuntura para as populações pobres são imensas, sendo agravadas pela baixa das ações humanitárias devido às restrições da circulação de pessoas e bens, dificultando a chegada dos trabalhadores humanitários às pessoas mais necessitadas. As medidas de lockdown em vários desses países interromperam a cadeia de abastecimento de alimentos, geraram o desemprego e a falta de renda e de assistência. Pequenos produtores rurais, que desempenham papel fundamental nos sistemas alimentares dos países em desenvolvimento, estão entre os mais afetados pela crise, tendo mesmo que se desfazerem de produtos perecíveis devido ao fechamento de mercados consumidores.

\section{CONCLUSÃO}

As crises sanitárias fazem parte da história da humanidade, mas devemos compreender que estamos para além de somente forças evolutivas naturais e independentes. A expansão descontrolada do capitalismo modifica condições ambientais e suga a natureza de forma não renovável, confundindo mesmo os limites entre o natural e o artificial. Para além das alterações próprias do vírus, se colocam as condições sociais em que esse se torna uma ameaça à humanidade, que foge ao tão buscado controle sobre a vida que os homens querem dominar em sua totalidade a todo custo. Além de detonar uma espetacular crise do sistema capitalista, cujas consequências ainda estão sendo mensuradas, a pandemia do Coronavírus descortinou, não para os críticos do modo de produção vigente, uma

\footnotetext{
${ }^{16}$ O documento da Oxfam (2020) centra sua análise em dez países e regiões em que a crise de fome extrema é mais grave e está se acirrando em decorrência da pandemia: lêmen, República Democrática do Congo, Afeganistão, Venezuela, Região do Sahel da África Ocidental, Etiópia, Sudão, Sudão do Sul, Síria e Haiti. Esses países concentram $65 \%$ das pessoas em situação de fome no mundo todo.

${ }^{17}$ Até 2014 o Brasil estava vencendo a guerra contra a fome, mas esse quadro começou a sofrer revesses a partir de 2015. Segundo a Oxfam (2020, p. 22), "Em 2018, o número de pessoas em situação de fome no Brasil aumentou em 100 mil (para 5,2 milhões) devido a um aumento acentuado nas taxas de pobreza e desemprego e a cortes radicais nos orçamentos para agricultura e proteção social. Isso incluiu cortes no programa Bolsa Família e, a partir de 2019, o desmantelamento gradual de políticas e órgãos bem-sucedidos estabelecidos por governos anteriores, incluindo o fechamento do CONSEA".
} 


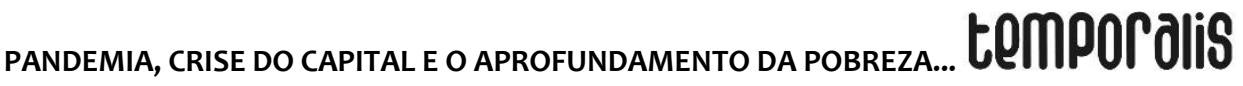

sociedade extremamente desigual e injusta, cuja busca pela acumulação de riquezas banaliza a vida, a tornando descartável em nome do funcionamento dos mercados.

Uma sociedade que, ao prezar pelo lucro, deixa expostas bilhões de pessoas a todo tipo de ameaça e barbárie. E em momentos de crise do capitalismo constatamos com mais veemência que vivemos em um mundo pensado e mantido para uma minoria: a pobreza se evidencia em níveis alarmantes; os sistemas de saúde públicos globais denunciam o descaso com as políticas sociais públicas, se efetivando como nichos de investimento e acumulação; a fome irrompe a realidade de países em uma era de tantas riquezas e potencialidades. O mercado, em seu movimento e conjecturas, não é capaz de garantir uma retoma econômica; o intervencionismo estatal se mostra necessário.

Estaremos caminhando para um modelo de Estado nos moldes de Keynes? Para se pensar essa possibilidade, devemos analisar a conjuntura atual, muito diferente do pós Segunda Guerra. Havia, naquele momento, uma convergência de fatores inéditos que possibilitaram essa estruturação social, política e econômica que edificaram os mais variados Estado de Bem-estar europeus. O contexto hoje não é promissor para isso: as taxas de crescimento após a crise de 1970 nunca foram retomadas; a argumentação neoliberal - que justamente condena esse intervencionismo - impregnou na sociedade impondo a ideia de que não há outra possibilidade, senão essa própria; a economia encontrou seu ápice da financeirização especulativa, desviando a possibilidade de grandes investimentos produtivos para a fetichização do capital. O que procuramos denunciar é que cada vez mais a classe trabalhadora sofre com as consequências mais intensas do descontrolado movimento do capital e sua reprodução em escala global; estamos regredindo a passos largos da possiblidade de uma sociedade justa e equânime. E essa distância aumentará enquanto o lucro motivar todas os investimentos e direcionamentos da humanidade.

\section{REFERÊNCIAS}

BANCO MUNDIAL. Poverty and shared prosperity. Reversals of Fortune. Washington (DC): World Bank Group, 2020.

BANCO MUNDIAL. La pobreza y la prosperidade compartida: armando rompecabezzas de la pobreza (panorama general). Washington (DC): Grupo Banco Mundial, 2018.

BARRUCHO, Luis. Coronavírus pode jogar até 14 milhões de brasileiros na pobreza, diz estudo. BBC News Brasil, Londres, 12 jun. 2020. Disponível em:

https://www.bbc.com/portuguese/brasil-53020785. Acesso em: 15 nov. 2020.

COLLETTI, L. Introdução à Seção Terceira do Livro III d'O Capital. In: COLLETTI, L. EI marxismo y el “derrumbe” del capitalismo”. México: Siglo XXI Editores, 1978. p. 49-57.

CRISE atual é 'diferente de tudo o que o mundo já viu' e terá consequências devastadoras para os mais pobres, diz economista chefe do FMI. G1 Economia, São Paulo, 16 jun. 2020. Disponível em: : https://g1.globo.com/economia/noticia/2020/06/16/crise-atual-ediferente-de-tudo-o-que-o-mundo-ja-viu-e-tera-consequencias-devastadoras-para-os-maispobres-diz-economista-chefe-do-fmi.ghtml. Acesso em: 20 jun. 2020.

Temporalis, Brasília (DF), ano 21, n. 41, p. 256-269, jan./jun. 2021. | ISSN 2238-1856 
FAN, Yi; ZHAO, Kai; SHI, Zheng-Li; ZHOU, Peg. Bat Coronoviruses in China. Viruses: Multidisciplinary Digital Publishing Institute (MDPI), v. 11, n. 3, mar. 2019. Disponível em: https://www.ncbi.nlm.nih.gov/pmc/articles/PMC6466186/. Acesso em: 20 jun. 2020.

FAO. Fome aumenta no mundo e na América Latina e no Caribe pelo terceiro ano consecutivo. Santiago de Chile: Escritório Regional da FAO para a América Latina e o Caribe, set./2018. Disponível em http://www.fao.org/americas/noticias/ver/pt/c/1152189/\#: :text=Segundo\%200\%20Estado\% 20da\%20Seguran\%C3\%A7a,a\%20fome\%20h\%C3\%A1\%20quatro\%20anos. Acesso em: 3 out. 2020.

FONTES, V. Coronavírus e a crise do capital: Entrevista com Virgínia Fontes. [Entrevista cedida ao] ANDES - Sindicato Nacional. Reproduzida por ADUFS - Associação dos Docentes da Universidade Federal de Sergipe. Aracaju, abr/2020. Disponível em: https://adufs.org.br/conteudo/1883/coronavirus-e-a-crise-do-capital-entrevista-comvirginia-fontes. Acesso em: 5 out. 2020.

GRAGNANI, Juliana. Por que o coronavírus mata mais as pessoas negras e pobres no Brasil e no mundo. BBC News Brasil, Londres, 12 jul. 2020. Disponível em: https://www.bbc.com/portuguese/brasil-53338421. Acesso em: 22 ago. 2020.

HARVEY, D. Política anticapitalista em tempos de COVID-19. In: DAVIS, Mike et al. (Orgs.) Corona vírus e a luta de classes. Teresina; Fortaleza: Terra sem Amos, 2020. p. 13-23.

HARVEY, D. A loucura da razão econômica: Marx e o capital no século XXI. São Paulo: Boitempo, 2018.

HARVEY, D. Os limites do capital. São Paulo: Boitempo, 2013.

HUBERMAN, Leo. História da riqueza do homem. Rio de Janeiro: Zahar Editores, 1982.

LEFEBVRE, Henri. Estrutura Social: a reprodução das relações sociais. In: FORACCHI, $M$. M.; MARTINS, J. de S. (Orgs.). Sociologia e Sociedade: Leituras de introdução à Sociologia. Rio de Janeiro: Livros Técnicos e Científicos Editora S/A - LTC, 1977.

MANDEL, Ernest. O Capitalismo Tardio. São Paulo: Abril, 1982.

MARX, K. O Capital: Crítica da economia política. Vol. I. Livro Primeiro: O processo de produção do capital. Editado por Friedrich Engels. São Paulo: Abril Cultural, 1984.

MARX, K. O Capital: Crítica da economia política. Vol. II. Livro Segundo: O processo de circulação do capital. Editado por Friedrich Engels. São Paulo: Abril Cultural. $1983 a$.

MARX, K. O Capital: Crítica da economia política. Vol. III. Livro Terceiro: O processo global da produção capitalista. Editado por Friedrich Engels. São Paulo: Abril Cultural, 1983b.

MARX, K; ENGELS, F. Manifesto Comunista. São Paulo: Boitempo, 2010. 
MÉSZÁROS, Istvàn. Para Além do Capital: rumo a uma teoria de transição. São Paulo: Boitempo, 2011.

NAÇÕES UNIDAS. Uma em cada três pessoas no mundo não tem acesso à água potável. ONU News, 18 jun. 2019. Disponível em: https://news.un.org/pt/story/2019/06/1676671. Acesso em: 22 set. 2020.

NACIONES UNIDAS. Informe de los Objetivos de Desarrollo Sostenible: 2020. Disponível em: https://unstats.un.org/sdgs/report/2020/The-Sustainable-Development-Goals-Report2020 Spanish.pdf. Acesso em: 25 set. 2020.

NERI, M. Efeitos da pandemia sobre o mercado de trabalho brasileiro: desigualdades, ingredientes trabalhistas e papel da jornada. FGV Social, Rio de Janeiro, set. 2020. Disponível em: https://www.cps.fgv.br/cps/bd/docs/Covid\&Trabalho-Marcelo_NeriFGV_Social.pdf. Acesso em: 5 out. 2020.

NETTO, J. P. Crise do capital e consequências societárias. Serviço Social e Sociedade, São Paulo, n. 111, p. 413-429, jul./set. 2012.

NETTO, J. P.; BRAZ, M. Economia política: uma introdução crítica. 8. ed. São Paulo: Cortez, 2012.

OXFAM. Comunicado de Impressa Oxfam Brasil. O vírus da fome: como o corona vírus está aumentando a fome em um mundo faminto, jul. 2020. Disponível em https://d2v21prk53tg5m.cloudfront.net/wp-content/uploads/2020/07/Informe-Virus-daFome-embargado-FINAL-1.pdf . Acesso em 07 out. 2020.

PINTO, M. B.; CERQUEIRA A. S. Reflexões sobre a pandemia da COVID-19 e o capitalismo. Libertas, Juiz de Fora, v. 20, nº 1, p. 38-52, jan./jul. 2020

SWEEZY, P. M. Teoria do desenvolvimento capitalista. Rio de Janeiro: Zahar Editores, 1982.

ZIBECHI, R. Corona vírus: a militarização das crises. In.: DAVIS, Mike et al (Orgs.) Corona vírus e a luta de classes. Terra sem amos: Brasil, 2020, p. 31-33.

Silvio Aparecido Redon Trabalhou na concepção e delineamento, análise e interpretação dos dados, redação e revisão crítica do artigo e aprovação da versão a ser publicada.

Graduado em Serviço Social pela Universidade Estadual de Londrina. Mestre e doutorando em Serviço Social e Política Social pela Programa de Pós-Graduação em Serviço Social e Política Social, pela mesma instituição.

Eliane Christine Santos de Campos Trabalhou na concepção e delineamento, redação e revisão crítica do artigo e aprovação da versão a ser publicada.

Graduada em Serviço Social pela Universidade Estadual de Londrina. Possui mestrado em Serviço Social e Política Social pela Universidade Estadual de Londrina e doutorado pela Pontifícia Católica de São Paulo. Professora titular da Universidade Estadual de Londrina - Departamento de Serviço Social. 